\title{
Enhanched External Counterpulsation Therapy Improves Clinical Outcomes, Quality of Life and Functional Effort Capacity in Patients with Symptomatic Heart Failure
}

\author{
Güçlendirilmiş Eksternal Kontrpulsasyon Tedavisi Semptomatik Kalp Yetmezliği Hastalarında \\ Klinik Sonuçları, Hayat Kalitesini ve Fonksiyonel Efor Kapasitesini lyileştirir
}

\section{Meltem REFiKER EGE', Özlem SORAN²}

\author{
'Yüksek Ihtisas Üniversitesi Tıp Fakültesi, Kardiyoloji Anabilim Dalı, Medical Park, Ankara Hastanesi, Kardiyoloji Kliniği, Ankara, Türkiye \\ ${ }^{2}$ Sanko Üniversitesi Tıp Fakültesi, Kardiyoloji Anabilim Dalı, Gaziantep, Türkiye; Pittsburgh Üniversitesi, Tıp Fakültesi, Kardiyoloji Kliniği,
}

EECP Laboratuvarı, Pensilvanya

\section{ABSTRACT}

Introduction: Symptomatic chronic heart failure is an important health problem that limits the daily life, quality of life, effort capacity and physiological condition of the patients. In subset of these patients symptoms persist despite optimal medical management. Enhanced External Counterpulsation (EECP) is a non-invasive Food and Drug Administration (FDA) approved therapy which improves symptoms and clinical outcomes in patients with heart failure. However, there is limited data in Turkish cohort. In this study, we investigated the clinical effects of EECP on multiple parameters in Turkish patients with symptomatic chronic heart failure.

Material and Methods: Twenty-one individuals who were diagnosed with symptomatic chronic heart failure (left ventricular ejection fraction $\leq 40 \%$ ) with New York Heart Association Class (NYHA) II-III were enrolled in the study. Patients were assigned to 35-session EECP treatment. NYHA classification, SF-36 quality of life questionnaire, Minnesota living heart failure questionnaire, quality of life index cardiac version-IV and Beck depression scale were assessed, and 6-minute walk tests were performed before and after EECP treatment.

Results: The mean age of the patients was $57.4 \pm 12.5$ years. EECP therapy resulted in significant improvement in NYHA functional class, quality of life index, effort capacity and pyhsiological condition in all patients without any adverse event $(\mathrm{p}=0.001)$.

Conclusion: Enchanced external counterpulsation treatment significantly improved clinical parameters and effort capacity in patients with symptomatic heart failure. These results suggest that EECP is an effective and a safe therapy in Class II-III heart failure patients whose symptoms persist despite optimal medical management.

Keywords: heart failure, symptom, quality of life, depression, EECP
ÖZ

Giriş: Semptomatik kronik kalp yetmezliği hastaların günlük hayatını, hayat kalitesini, efor kapasitesini ve psikolojik durumunu olumsuz yönde etkileyen önemli bir sağlık problemidir. Optimal medikal tedaviye rağmen bir grup hastada şikâyetler devam eder. Güçlendirilmiş Eksternal Kontrpulsasyon (EECP) tedavisi kalp yetmezliği hastalarında semptomları ve klinik sonuçları iyileştiren, FDA (Food and Drug Administration) onaylı, girişim gerektirmeyen bir tedavi yöntemidir. Buna rağmen Türk hastalarda kısıtlı bilgi mevcuttur. Bu çalışmada, semptomatik kronik kalp yetmezliği olan Türk hastalarda EECP'nin birçok parametreye etkisi araştırılmıştır.

Materyal ve Metodlar: New York kalp yetmezliği sinıf (NYHA) IIIII olan semptomatik kronik kalp yetmezliği (sol ventrikül ejeksiyon fraksiyonu $\leq \% 40$ ) tanısı almış 21 hasta çalışmaya dâhil edilmiştir. Hastalar 35 seans EECP tedavisine alınmıștır. Hastalara NYHA sınıflaması, "SF36 quality of life" (yaşam kalitesi ölçeği) anketi, "Minnesota living heart failure" (Minnesota kalp yetmezliği ile yaşam) anketi, "quality of life indeks cardiac version-IV" (yaşam kalitesi indeksi, kardiyak versiyonu) skorlaması ve "Beck" depresyon skalası uygulanarak, tedavi öncesi ve sonras 6 dakika yürüme testleri yapılmıştır.

Bulgular: Hastaların ortalama yaşı $57,4 \pm 12,5$ yıl idi. Tüm hastalarda EECP tedavisi hiçbir advers olay görülmeden NYHA fonksiyonel sinıflaması, hayat kalitesi indeksi, efor kapasitesi ve psikolojik durumda belirgin iyileşmeye neden olmuştur $(\mathrm{p}=0,001)$.

Sonuç: Semptomatik kalp yetmezliği hastalarında EECP tedavisi klinik parametreleri ve efor kapasitesini iyileştirir. Bu sonuçlar göstermiştir ki EECP tedavisi optimal medikal tedaviye rağmen semptomları devam eden NYHA sınıf II-III hastalarda etkili ve güvenli bir tedavi yöntemidir.

Anahtar Sözcükler: kalp yetmezliği, semptom, hayat kalitesi, depresyon, EECP

Cite this article as: Ege MR, Soran Ö. Enhanched External Counterpulsation Therapy Improves Clinical Outcomes, Quality of Life and Functional Effort Capacity in Patients with Symptomatic Heart Failure. YIU Saglik Bil Derg 2020;1:104-108.

Correspondence Address/Yazışma Adresi: Dr. Meltem REFiKER EGE, Yüksek İhtisas Üniversitesi Tıp Fakültesi, Kardiyoloji Anabilim Dalı, Medical Park, Ankara Hastanesi, Kardiyoloji Kliniği, Ankara, Türkiye E-mail: meltemrefikerege@yiu.edu.tr; R.E.: https://orcid.org/0000-0002-0621-6000, 0̈.S.: https://orcid.org/000-0002-4868-235x 


\section{Introduction}

Heart failure is a common clinical condition with high morbidity and mortality rates. Despite advances in medical therapy and invasive procedures, it is still a serious cardiovascular condition leading to cardiovascular life threatening events, poor prognosis and degradation of quality of life (1). New York Heart Association (NYHA) class, depression and the 6-min walk test have been reported to be the predictors of quality of life in patients with heart failure (2). The primary objective of heart failure treatment is to improve symptoms, health related quality of life and reduce mortality and morbidity (3). Despite optimal medical treatment, there are still many patients who suffer from persistent symptoms and had to restrict their activities. Enhanced external counterpulsation (EECP), is a non-invasive therapy that has been approved by the United States Food and Drug Administration (FDA) for the management of heart failure. In patients with heart failure, EECP treatment was associated with significant improvements in exercise capacity, exercise duration and quality of life (4).

The aims of our study are to investigate the clinical effects of EECP treatment on multiple parameters associated with quality of life and physiological condition in Turkish patients with symptomatic heart failure who have been on optimal medical treatment.

\section{Methods}

Twenty-one individuals who were diagnosed with symptomatic chronic heart failure (left ventricular ejection fraction $\leq 40 \%$ ) with New York Heart Association Class (NYHA) II-III were enrolled in the study. The medical history and current medications of the patients were collected from the patients' medical records. All patients were on optimal medical treatment. Twenty-four percent of the patients had biventricular pacemaker and $38 \%$ had internal cardiac defibrillator. Patients with unstable angina, acute myocardial infarction, decompensated heart failure, uncontrolled systemic hypertension ( $\geq 180 / 110 \mathrm{mmHg}$ ), severe aortic regurgitation, severe cardiac arrhytmia that would interfere with EECP triggering, acute deep vein thrombosis, phlebitis, use of anticoagulant with INR $>3$, haemorrhagic diathesis, pregnancy, abdominal aortic aneurysm $\geq 5 \mathrm{~cm}$, aortic dissection, and those who refused to sign the informed consent or were not able to complete the questionnaires on their own are excluded from the study. Eligible patients were referred for EECP therapy by the same cardiologist, and all patients signed a consent form. This study was performed according to the Helsinki Declaration.

EECP is a non-invasive FDA approved therapy for the management of congestive heart failure. The EECP therapy consists of electrocardiogram-gated rapid, sequential compression of the lower extremities taking place during diastole, followed by simultaneous decompression during systole. It consists of three sets of pneumatic cuffs attached to each of the patient's legs at the calf, and lower and upper thigh. The inflation of the cuffs is triggered by a computer, inflation and deflation timing are followed by a finger plethysmogram, and the timing of the inflation is based on the $\mathrm{R}$ wave of the electrocardiogram. The inflation of the cuffs during diastole produces aortic counterpulsation, resulting in diastolic augmentation of blood flow which leads to an improved coronary perfusion during diastole. On the other hand, simultaneous deflation of the cuffs before the onset of systole causes systolic unloading, and decreases the cardiac workload. Although the hemodynamic effects are similar to those of intra-aortic balloon pump, EECP therapy also increases venous return.

All patients were assigned to 35 -session EECP treatment. Each treatment session was 1 hour/day.

Three pneumatic cuffs were placed around the lower limbs, upper limbs and buttocks, and were inflated sequentially upward at the onset of diastole, and released simultaneously before the onset of systole. All patients were monitored with pulse oximetry during the treatment session, and were weighed daily. Patients whose oxygen saturation dropped by $\geq 4 \%$ or whose weight increased during treatment were re-evaluated for the continuation of the therapy. The applied pressure was 280-300 $\mathrm{mmHg}$, and this was reached within 5 minutes of the initiation of the treatment.

All patients were classified according to the NYHA functional classification by the same blinded medical personnel before and after the treatment. For the evaluation of the functional effort capacity, 6-minute walk test (6MWT) was performed Minnesota Living with Heart Failure questionnaire (MLHF-Q), SF-36 quality of life questionnaire, quality of life index cardiac version-IV, and Beck depression scale were assessed before and after EECP treatment.

MLHF-Q is a heart failure specific questionnaire consisting of 21 items with 6-point response scale from 0 to 5, leading to a total score. A higher score indicates worse health score (5). The SF-36 is a self-administrated questionnaire designed for assessment of health related quality of life. It consists of 36 items divided into 8 subscales of health: i.e., physical functioning, role physical, bodily pain, general health, vitality, social function, role emotional and mental health. All scores are transformed to a range from 0 to 100 , with higher scores indicating better health status (6). Quality of life index cardiac version scale is a measure of subjective well-being that assesses satisfaction with various domains of life. Seventy-four items divided into two parts: Part 1 (Satisfaction; 37 items) and Part 2 (Importance; 37 items). The scoring scheme provides a score range from 0 to 30 , with higher scores reflecting higher levels of quality of life (7). Beck depression scale is a 21-question self-report inventory, relating to cognitive, affective and somatic symptoms of depression. Each response is scored from 0 to 3, indicating the severity 
of symptom and at least the severity of depression (range 0 to 63 ). Based on the scores, severity of depressive symptoms was categorized into the following groups: minimal (0-13), mild (14-19), moderate (20-28), and severe (29-63) (8).

Before measuring 6-minute walk distance, a physical therapist explained the procedure to the patients. They were told to walk as fast and long as possible on a 30-meter walkway that was marked every 3 meters. Patients were allowed to stop and rest or reduce their walking speed if they felt shortness of breath or fatigue. The test was suspended if the patients experienced chest pain, dyspnea, leg cramps, hydrosis, and cyanosis.

The assessment of the NYHA functional capacity, questionnaires and the 6MWT were made by the same blinded medical personnel.

\section{Statistical Analyses}

The SPSS 19 (SPSS Inc., an IBM company; Chicago, USA) package was used for statistical analysis. Results are presented as mean $\pm \mathrm{SD}$. In comparing the results of patients before and after the EECP treatment, continuous variables that were normally distributed were analyzed with the 2-tailed t test, and unequally distributed variables were analyzed with MannWhitney $U$ test. A p-value less than 0.05 was considered as statistically significant.

\section{Results}

The mean age of the patients was $57.4 \pm 12.5$ years; $76 \%$ were male, $80 \%$ had ischemic heart failure, $52 \%$ had a previous history of coronary stent implantation, $52 \%$ had coronary artery bypass

Table 1. Clinical characteristics of study population

\begin{tabular}{|c|c|c|c|}
\hline & $\mathbf{n}$ & $\%$ & Mean \pm SD \\
\hline Gender male/female & $16 / 5$ & & \\
\hline Age & & & $57.4 \pm 12.5$ \\
\hline Smoking & 2 & 9.5 & \\
\hline Hypertension & 12 & 57.1 & \\
\hline Diabetes mellitus & 8 & 38.1 & \\
\hline Hyperlipidemia & 12 & 57.1 & \\
\hline $\begin{array}{l}\text { Heart Failure (LVEF } \leq 40 \%) \text { - } \\
\text { ischemic CMP - dilate CMP }\end{array}$ & $\begin{array}{c}21 \\
17 \\
4\end{array}$ & $\begin{array}{l}100 \\
80.9 \\
19.1\end{array}$ & \\
\hline Coronary stent & 11 & 52.4 & \\
\hline CABG-O & 11 & 52.4 & \\
\hline $\mathrm{PAH}$ & 2 & 9.5 & \\
\hline CKD & 4 & 19 & \\
\hline ICD & 6 & 38.1 & \\
\hline CRT-D & 5 & 23.8 & \\
\hline ACE-I/ARB & $11 / 10$ & $52.4 / 47.6$ & \\
\hline Beta-blocker & 20 & 95.2 & \\
\hline Furosemide & 21 & 100 & \\
\hline Spiranalactone & 20 & 95.2 & \\
\hline Digoksin & 19 & 90.4 & \\
\hline Ivabradine & 15 & 71.4 & \\
\hline Statin & 12 & 57.1 & \\
\hline Clopidogrel & 8 & 38.1 & \\
\hline Acetylsalicylic acid & 14 & 66.7 & \\
\hline Warfarin & 2 & 9.5 & \\
\hline $\mathrm{AF}$ & 1 & 4.7 & \\
\hline LBBB & 5 & 23.8 & \\
\hline Fasting glucose & & & $137.2 \pm 44.1$ \\
\hline Total cholesterol & & & $326 \pm 181.4$ \\
\hline Triglyceride & & & $134.3 \pm 42.1$ \\
\hline LDL-C & & & $102.5 \pm 41.2$ \\
\hline HDL-C & & & $38.0 \pm 11.3$ \\
\hline ALT & & & $28.5 \pm 13.8$ \\
\hline AST & & & $26.6 \pm 7.5$ \\
\hline Urea & & & $29.9 \pm 24.1$ \\
\hline Creatinine & & & $2.3 \pm 6.9$ \\
\hline Haemoglobin & & & $12.2 \pm 1.6$ \\
\hline Haematocrit & & & $39.7 \pm 5.1$ \\
\hline
\end{tabular}

LVEF, left ventricular ejection fraction; CMP, cardiomyopathy; CABG-O, coronary artery bypass greft operation; PAH, peripheric artery disease; CKD, chronic kidney disease; ICD, internal cardiac defibrillator; CRT-D, cardiac resynchronization-defibrillator; ACE-I/ARB, ACE-inhibitors/angiotensin-II receptor blockers; AF, atrial fibrillation; LBBB, left bundle branch block 
Table 2. The effects of EECP on multiple parameters associated with quality of life, daily life, physiological condition and functional effort capacity

\begin{tabular}{|c|c|c|c|c|}
\hline & Before EECP & After EECP & $\mathbf{N}$ & $\mathbf{P}$ \\
\hline NYHA class & $1.6 \pm 1.5$ & $0.6 \pm 0.7$ & 21 & 0.001 \\
\hline SF36 score & $75.5 \pm 5.2$ & $119.9 \pm 13.6$ & 21 & 0.001 \\
\hline BECK score & $8.2 \pm 7.9$ & $2.4 \pm 4.6$ & 21 & 0.001 \\
\hline Quality of life index cardiac version-IV & $288.8 \pm 34.1$ & $346.3 \pm 49.5$ & 21 & 0.001 \\
\hline
\end{tabular}

NYHA, New York Heart Association.

surgery, 57\% had hypertension, 38\% had diabetes mellitus and $57 \%$ had hyperlipidaemia (Table 1). On the average, patients underwent an EECP treatment course of 35 hours with $100 \%$ completing the therapy. There were no significant changes in concomitant medication uses, and no serious adverse effects throughout the treatment.

EECP therapy resulted in significant improvement in NYHA functional class $(1.6 \pm 1.5$ vs $0.6 \pm 0.7, p=0.001)$. After the treatment, SF-36 score increased significantly (75.5 \pm 5.2 vs $119.9 \pm 13.6, \mathrm{p}=0.001$ ). All patients showed significant improvement in the Minnesota living with heart failure score after the 35 -session of the treatment $(66.7 \pm 29.5$ vs $22.8 \pm 26.2$, $\mathrm{p}=0.001$ ). The physiological status of patients improved after the end of treatment (Beck score $8.2 \pm 7.9$ vs $2.4 \pm 4.6, \mathrm{p}=0.001$ ). Quality of life index cardiac version-IV scores also showed gradual improvement after the 35 -session treatment $(288.8 \pm 34.1$ vs $346.3 \pm 49.5, \mathrm{p}=0.001)$. 6- minute walk test results improved significantly after the treatment $(273 \pm 46.8$ vs $364 \pm 50.9$, $\mathrm{p}=0.001)$. (Table 2).

\section{Discussion}

Heart failure is a burden to patients and health care systems (9). Despite of markedly improved options of treatment, chronic heart failure is associated with recurrent worsening of symptoms. Decreased physical activity depending on symptoms is associated with adverse phycho-social outcomes and poor quality of life including depressive symptoms in patients with heart failure. Independent of other factors, low health related quality of life has been shown to impact on hospitalisations and mortality (10). Depressive symptoms also correlate with poorer quality of life in patients with heart failure (11). NYHA functional status also found to be correlated with the prevalence of depression (12). All these findings may support the opinion that quality of life, physiological status, and functional capacity are correlated with each other. This may be because worse physiological status has a negative effect on adherence to therapy. Poor medication adherence may have adverse effects on progression of heart failure, and may affect health related quality of life. On the other hand, heart failure patients also have lower exercise capacity. In many studies, it was shown that patients with a $6 \mathrm{MWD}<300$ meters have increase mortality and morbidity (13). Promotion of life quality is one of the major goals of cardiac patients. Poor health related quality of life is a predictive factor for hospital readmissions (14). Physical mobility and emotional status play a strong role in determining health related quality of life. This study demonstrated that 35-session EECP treatment resulted in significant improvement in many parameters associated with quality of life including depression and 6-minute walk distance in patients who were under optimal medical treatment. By positively improving all these factors, EECP provides valuable support to the management of heart failure.

A study of 26 patients with heart failure (class II-III NYHA and average $\mathrm{EF}$ of $23 \%$ ) showed clinical benefit without any major adverse cardiac effect (4). In the large randomized PEECH trial (15), patients with heart failure who were randomised to EECP treatment showed at least a 60 -second increase in exercise duration, and significant improvement in NYHA classification at the 6-month post treatment period. In addition, EECP has been shown to reduce emergency room visits and hospitalization in coronary artery disease patients with left ventricular dysfunction. The data from the International EECP Patient Registry (IEPR) showed that in heart failure patients with an $\mathrm{EF}$ of $35 \%$ or less, $81 \%$ had no exacerbation of congestive heart failure during twoyear follow-up (16).

In patients with left ventricular dysfunction, EECP therapy increases cardiac output and cardiac index by increasing right atrial mean pressure and pulmonary capillary wedge pressure. During the cuff deflation, it reduces afterload, and decreases cardiac workload. In ischemic myocardium, by increasing coronary blood flow, EECP therapy is thought to promote myocardial collateralization. Increased coronary blood flow and thus shear stress also improve coronary endothelial function promoting new vessel formation by angiogenesis, and arteriogenesis (17). In summary, mechanism of action studies showed that EECP exhibits its clinical effectivity through neurohormonal and endothelial function improvement, and collateral development. Our findings suggest that in addition to these hemodynamic effects EECP treatment has a positive impact on quality of life, exercise capacity, and physiological status. 
The small sample size of the study is the limitation of our study, thus this limits our ability to generalize the results. The lack of long term follow-up is another important limitation of our study. Future studies with larger sample sizes are needed to confirm these results.

In conclusion, EECP is an effective and also a safe therapy in patients with Class II-III heart failure whose symptoms persist despite optimal medical treatment.

Peer-review: Externally peer-reviewed.

Author Contributions: Concept - MRG, ÖS; Design - MRG, ÖS; Supervision - MRG, ÖS; Resource - GIK, CE; Materials - MRG, ÖS; Data Collection and/ or Processing - MRG, ÖS; Analysis and/or Interpretation - MRG, ÖS; Literature Search - MRG; Writing - MRG; Critical Reviews - ÖS.

Conflict of Interest: The authors do not have any conflicts of interest.

Financial Disclosure: The authors declared that this study has received no financial support.

Hakem Değerlendirmesi: Dış Bağımsız.

Yazar Katkıları: Fikir - MRG, ÖS; Tasarım - MRG, ÖS; Denetleme - MRG, ÖS; Kaynaklar MRG, ÖS; Malzemeler- MRG, ÖS; Veri Toplanması ve/veya Işlemesi - MRG, ÖS; Analiz ve/ veya Yorum - MRG, ÖS; Literatür Taraması - MRG; Yazıyı Yazan - MRG; Eleştirel Inceleme - ÖS.

Çıkar Çatışması: Yazarların herhangi bir çıkar çatışması bulunmamaktadır.

Finansal Destek: Yazarlar bu çalışma için finansal destek almadıklarını beyan etmişlerdir.

\section{References}

1. Roger VL, Weston SA, Redfield MM, Hellermann-Homan JP, Killian J, Yawn $\mathrm{BP}$, et al. Trends in heart failure incidence and survival in a communitybased population. JAMA 2004;21;292:344-50. https://doi.org/10.1001/ jama.292.3.344

2. Peters-Klimm F, Kunz CU, Laux G, Szecsenyi J, Müller-Tasch T. Patientand provider-related determinants of generic and specific health-related quality of life of patients with chronic systolic heart failure in primary care: a cross-sectional study. Health Qual Life Outcomes 2010;8:98. https://doi. org/10.1186/1477-7525-8-98

3. Neumann T, Biermann J, Erbel R, Neumann A, Wasem J, Ertl G, D, et al. Heart failure: the commonest reason for hospital admission in Germany: medical and economic perspectives. Dtsch Arztebl Int 2009;106:269-275. https://doi. org/10.3238/arztebl.2009.0566
4. Soran O, Fleishman B, Demarco T, Grossman W, Schneider VM, Manzo K, et al. Enhanched external counterpulsation in patients with heart failure: A multi-center feasibility study. Congest Heart Fail 2002;8:204-208. https://doi. org/10.1111/j.1527-5299.2002.01731.x

5. Rector TS, Kubo SH, Cohn JN. Patients' self-assessment of their heart failure: content, reliability and validity of a new measure, The Minnesota Living with Heart Failure Questionnaire. Heart Fail 1987;3:198-209.

6. Aaronson NK, Muller M, Cohen PD, Essink-Bot ML, Fekkes M, Sanderman $\mathrm{R}$, et al. Translation, validation and norming of the Dutch language version of the SF-36 Health Survey in community and chronic disease populations. J Clin Epidemiol 1998;51:1055-1068. https://doi.org/10.1016/s08954356(98)00097-3

7. Ferrans CE, Powers MJ. Psychometric assessment of the Quality of Life Index. Res Nurs Health 1992;15:29-38. https://doi.org/10.1002/nur.4770150106

8. Beck AT, Ward CH, Mendelson M, Mock J, Erbaugh J. An inventory for measuring depression. Arch Gen Psychiatry 1961;4:561-571. https://doi. org/10.1001/archpsyc.1961.01710120031004

9. Mejhert M, Kahan T, Person H, Edner M. Predicting readmissions and cardiovascular events in heart failure patients. Int J Cardiol 2006;109:108-113. https://doi.org/10.1016/j.ijcard.2005.07.015

10. Faller H, Störk S, Schowalter M, Steinbüchel T, Wollner V, Ertl G et al. Is health related quality of life an independent predictor of survival in patients with chronic health failure? J Psychosom Res 2007;63:533-538. https://doi. org/10.1016/j.jpsychores.2007.06.026

11. Murberg TA, Furze G. Depressive symptoms and mortality in patients with congestive heart failure: a six year follow up study. Med Sci Monit 2004;10:CR643-648. https://www.medscimonit.com/download/index/ idArt/13229

12. Rutledge T, Reis VA, Linke SE, Greenberg BH, Mills PJ. Depression in heart failure: a meta-analytic review of prevelance, intervention effects, and associations with clinical outcomes. J Am Coll Cardiol 2006;48:1527-1537. https://doi.org/10.1016/j.jacc.2006.06.055

13. Shah MR, Hasselblad V, Gheorghiade M, Adams KF Jr, Swedberg K, Califf $\mathrm{RM}$, et al. Prognostic usefulness of the six-minute walk in patients with advanced congestive heart failure secondary to şschemic or nonischemic cardiomyopathy. Am J Cardiol 2001;88:987-993. https://doi.org/10.1016/ s0002-9149(01)01975-0

14. Mejhert M, Kahan T, Persson H, Edner M. Predicting readmissions and cardiovascular events in heart failure patients. Int J Cardiol 2006;109:108-113. https://doi.org/10.1016/j.ijcard.2005.07.015

15. Feldman AM; for the PEECH investigators. Results of PEECH (Prospective evaluation of EECP in Heart Failure). American College of Cardiology Conference. Orlando, March 8, 2005.

16. Soran O, Kennard ED, Kfoury AG, Kelsey SF; IEPR Investigators. Two- year clinical outcomes after enhanced external counterpulsation (EECP) therapy in patients with refractory angina pectoris and left ventricular dysfunction (report from the International EECP Patient Registry). Am J Cardiol 2006;97:17-20. https://doi.org/10.1016/j.amjcard.2005.07.122

17. Manchanda A, Soran O. Enhanched external counterpulsation and future directions: step beyond medical management for patients with angina and heart failure. J Am Coll Cardiol 2007;50:1523-1537. https://doi.org/10.1016/j. jacc.2007.07.024 